\title{
Analysis of Layout of Yogyakarta Airport Railway Station and Its Integration with Tugu Railway Station
}

\author{
Prabendra A. Atmakusuma \\ Ministry of Public Works and Housing, Jakarta, INDONESIA \\ prabendra.ardhan@gmail.com \\ Danang Parikesit \\ Department of Civil and Environmental Engineering, Universitas Gadjah Mada, Yogyakarta, INDONESIA \\ dparikesit@ugm.ac.id
}

\begin{abstract}
The government of Indonesia plans to build new airport that is located in Temon Sub-district, Kulon Progo Regency. However, the distance of the airport is quite far from the center of Yogyakarta City, therefore it is necessary to build a railway that functioned as a connector. The operating airport railway would then means an Airport Railway Station that is located in the center of Yogyakarta City, in order to accommodate the fluency of railway operation. This paper is intended to give information on the layout design, and also the location of Airport Railway Station in the center of Yogyakarta City. To generate layout of railway that is integrated with Tugu Railway Station of Yogyakarta, the methods used were: determining the station classification, determining the zone, the circulation and wayfinding, so that the passengers could move fluently. Based on the analysis result, the Airport Railway Station has categorized a large class station, with its location was designed separately from the Tugu Railway Station, but integrated with 52 meters long tunnel in south of the Airport Railway Station. The layout design of the Airport Railway Station was designed to be two levels and with two platforms with land necessity of $9100 \mathrm{~m}^{2}$, and was predicted to serve 515 passengers per rush hour.
\end{abstract}

Keywords: airport; layout design; integration; station location; station.

\section{INTRODUCTION}

Adisutjipto Airport that located in Sleman Regency, Yogyakarta, is an airport that used as military and commercial airport for domestic and international civil aviation, which currently managed by PT. Angkasa Pura I (Persero). There are two main problems that arise regarding the Adisutjipto Airport operations, which are the limited capacity of landside and airside. Based on total data on traffic movement of air transportation from PT Angkasa Pura I (Persero), the total passengers that need to be served by Adisutjipto Airport in 2015 was 6.2 million passengers per year. This number far exceeds the airport capacity that can only hold 1.2 million passengers per year, which resulting to overcapacity on the airport terminal building. While as the Air Force flight that operate simultaneously with commercial flight often cause traffic congestion from the airside facility. This then added to the obstacle presence that cause runway could only be built 2200 meters, causing Adisutjipto Airport to suffer from overcapacity from both the airside and landside facilities. To serve the growing number of passengers, and to maintain the quality of airport services on prime, based on the Decree of Minister of Transportation Number KP 1164 (Minister of
Transportation, 2013), new airport would be built as the replacement for Adisutjipto Airport, which will be located in Temon Sub-district, Kulon Progo Regency, Special Region of Yogyakarta.

However, the location transfer of commercial airport from Adisutjipto Airport to Temon Sub-district, Kulon Progo Regency, which is located about $45 \mathrm{~km}$ from the center of Yogyakarta City causes new problem in terms of accessibility and travel time that quite long when using road transportation mode, which is around 1 hour; therefore, related parties are planning to build a railway to the area. With the operation of airport railway, then it would be necessary to build Airport Railway Station that is located in the center of Yogyakarta City, in order to accommodate the fluency of the railway operation.

This paper aims to give analysis on location determination and layout design of the Airport Railway Station that integrates with Yogyakarta Station. The determination of station location would be important, considering the high amount of long-distance railway passengers and local passengers that the Yogyakarta Station been serving. It is expected that by determining the right location and with good layout design, the 
station could serve the passengers rides and other supporting activities without reducing the quality, security, comfort, and safety of the passengers.

The location for Airport Railway Station in which around the Yogyakarta Station was determined based on the National Spatial Plan and Detailed Spatial Plan of Yogyakarta City. The design of the station described in this paper was focused on the layout design, from the passengers' necessity side, which includes building component, also the supporting facility and platform; as for the architectural and structural sides, parking area size and passenger drop-off, were not discussed in this paper.

\section{REVIEW OF PREVIOUS RESEARCH}

Anggoro (2015) designed the Airport Railway Station layout and its integration with airport, by taking case study in the Airport Railway Station on Kulon Progo Regency, Yogyakarta. Furthermore, Hunaify (2015) conducted the geometric designing of railway as transportation to the new airport of Yogyakarta, by calculating the disaster factor which took the case study on the railway plan in Kedundang StationYogyakarta New Airport-Wojo Station. At the same time, Siregar (2015) conducted analysis on the estimation of passengers demand on the airport railway development plan in Kulon Progo.

\section{METHODOLOGY}

The location for Airport Railway Station in which around the Yogyakarta Station was determined based on the National Spatial Plan and Detailed Spatial Plan of Yogyakarta City. The data used in this designing were primary and secondary data. The obtained primary data was in form of clearance times that was acquired from conducting observation and field survey, also data on station users movement pattern, passengers characteristics data, and prediction on passengers movement in the station, that were gained from random sampling questionnaires. As for the secondary data, it was sourced from the Indonesian Railways Company Operation Area 6 Yogyakarta (PT KAI DAOP 6 Yogyakarta), Railink Ltd. (PT. Railink, 2013), and research of Siregar (2015). To fulfill the design objectives, the methodology framework was designed as shown as in Figure 1.

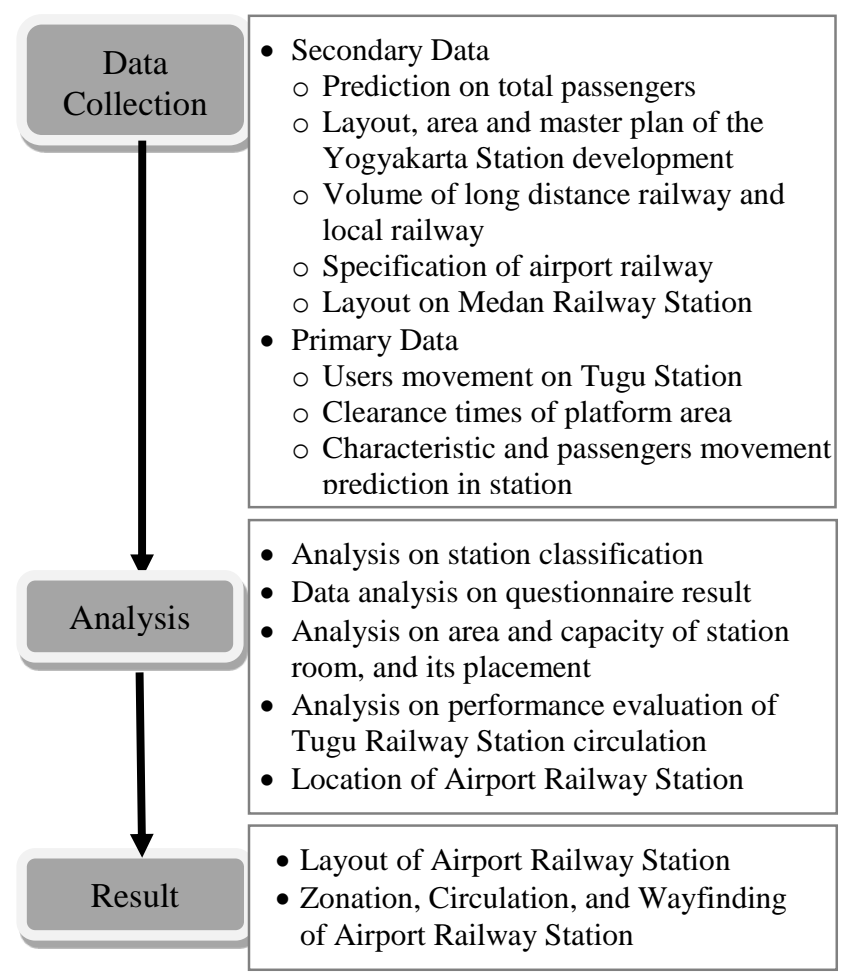

Figure 1. Design Flowchart

\section{RESULT AND DISCUSSION}

\subsection{Analysis and Classification of Station}

Determination of the station's class used the Regulation of Ministry of Transportation Number 33 Year 2011 as the reference, which included 6 (six) criteria that based on (1) railway operational facility, (2) total of railway tracks, (3) supporting facility, (4) traffic frequency, (5) total daily passengers, and (6) total goods. Accumulated credit score that obtained was 71 credit scores, with each criterion gave contribution as shown as Table 1.

Table 1. Criteria and the weight of credit score provided in the determination of the station classification

\begin{tabular}{|c|c|c|}
\hline Criteria & $\begin{array}{l}\text { Credit } \\
\text { Score }\end{array}$ & Note \\
\hline $\begin{array}{l}\text { Railway } \\
\text { Operational Facility }\end{array}$ & 25 & $\begin{array}{l}\text { Designed to have complete } \\
\text { railway signal, } \\
\text { telecommunication, and } \\
\text { electrical installations }\end{array}$ \\
\hline Railway Route & 4 & Designed to have 2 routes \\
\hline Supporting Facility & 13.5 & $\begin{array}{l}\text { Completed with supporting } \\
\text { and special supporting facility }\end{array}$ \\
\hline Traffic Frequency & 13.5 & Serving 62 trips in a day \\
\hline Total Passengers & 14 & $\begin{array}{l}\text { Predicted to serve } 515 \\
\text { passengers per rush hour }\end{array}$ \\
\hline Total Goods & 1 & 0 ton \\
\hline
\end{tabular}




\subsection{Data Analysis on Questionnaire Results}

Questionnaires were distributed to 100 respondents of air transportation users in Adisutjipto Airport. This questionnaire survey was intended to discover the general characteristic of airline passengers, perception on provision of airport railway, and to know the facility that became the priority, also the distribution of passengers inside the station.

Passengers' characteristic survey was intended to find out the general characteristic of airline passengers. Based on the result, majority of passengers travel to visit family relatives, therefore they are included in category of leisure users and tourists - which are type of users that rarely use the station and are usually unfamiliar with the station situation. Therefore, a good wayfinding system is required.

Next survey was conducted to discover the respondents' perception on airport railway. Information obtained from this survey would be used as a consideration in determining the area size or number of station's facilities. Respondents were given question on what transportation modes they would use to go to Yogyakarta Station if an Airport Railway Station is built in Yogyakarta Station. The data from survey results shown in Figure 2.

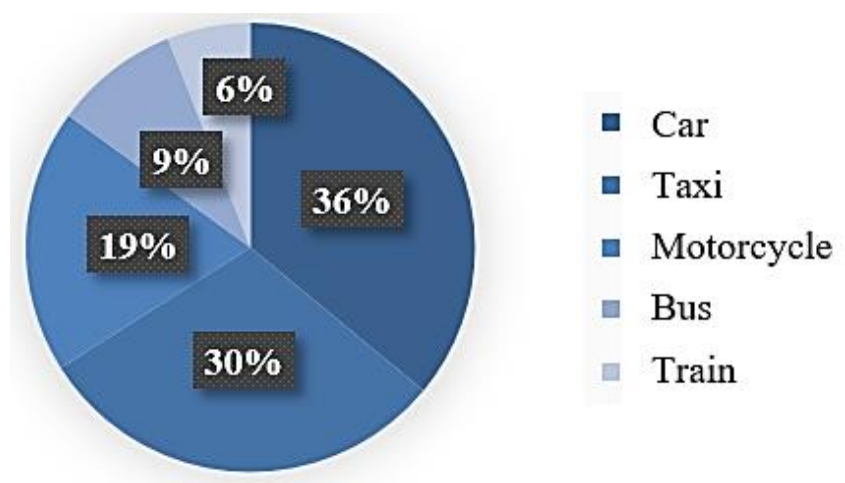

Figure 2. Percentage of transportation mode choices to Airport Railway Station

To facilitate the passengers with their luggage, the Airport Railway Station is planned to have an in-town check-in facilities or porter facilities. In this survey respondents were asked questions about the types of facilities that they might use at the station, as presented in Figure 3.

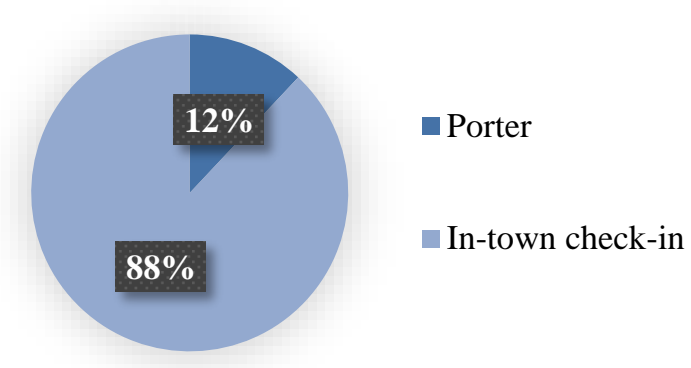

Figure 3. Percentage of facilities the passengers would choose to help with their luggage

Further survey was on the pattern of passengers' distribution in the station. This survey was intended to discover the facility that became respondents' priority in the station, and to know the passengers' distribution inside the station. The result of this survey would become the reference in determining the station's facilities location and the circulation of passengers inside the station. In this survey, the respondents were given the choice of first and second priority facilities to be used when in the station; these facilities beforehand had been grouped into seven categories, which are facility one is prayer room (musholla), facility two is waiting room, facility three is shops or convenience stores, facility four is restaurant, facility five is public toilet, facility six is maternity room, facility seven is other rooms, which are ATM center, travel agent, money changer, and smoking area. The matrix table that states the magnitude of movement, and desire line that states pattern of passengers' movement inside the station shown in Table 2 and Figure 4.

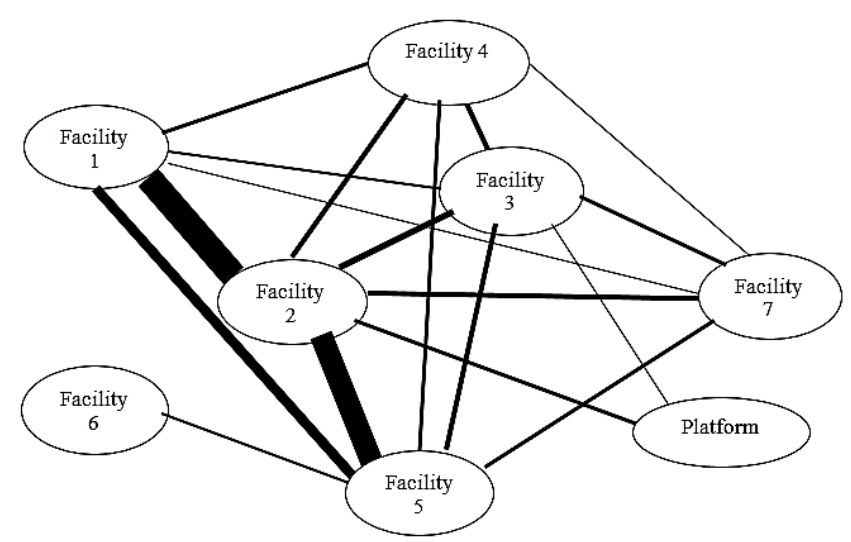

Figure 4. Desire line of passengers' movement inside the station 
Table 2. Matrix on passengers' movement inside the station

\begin{tabular}{lllllllll}
\hline \multirow{2}{*}{ Origin } & Destination & \multicolumn{7}{l}{} \\
\cline { 2 - 8 } & Facility 1 & Facility 2 & Facility 3 & Facility 4 & Facility 5 & Facility 6 & Facility 7 & Platform \\
\hline Facility 1 & & 527 & 0 & 316 & 527 & 0 & 0 & 0 \\
Facility 2 & 2001 & & 421 & 527 & 2001 & 0 & 316 & 316 \\
Facility 3 & 211 & 211 & & 211 & 211 & 0 & 105 & 105 \\
Facility 4 & 0 & 0 & 211 & & 0 & 0 & 0 & 0 \\
Facility 5 & 527 & 105 & 316 & 316 & & 105 & 211 & 0 \\
Facility 6 & 0 & 0 & 0 & 0 & 105 & & 0 & 0 \\
Facility 7 & 105 & 105 & 211 & 105 & 105 & 0 & 0 \\
\hline
\end{tabular}

\subsection{Station Rooms and Its Locating}

The area size and capacity of station was calculated with the applicable regulations in Indonesia and various regulations that are applicable abroad. For several rooms, the regulations used were the one applicable on abroad, because based on discussion result of PT. Railink, the Airport Railway Station was planned to be of large and international class. Station design used the Level of Service A (area of 3.24 $\mathrm{m} /$ person) with the consideration that the station is opened for the first time at opening year and the passenger growth level has not been known. Therefore, by using the Level of Service A, when the passengers' growth is present, the station is expected to be able to serve the passengers well without reducing the passengers' comfort level.

The placing of service rooms and public rooms of the station was based on the first priority of facility the passengers' chose based on the survey result. Therefore, assessment on facility rank that the passengers need most could be conducted, as shown as in Figure 5.

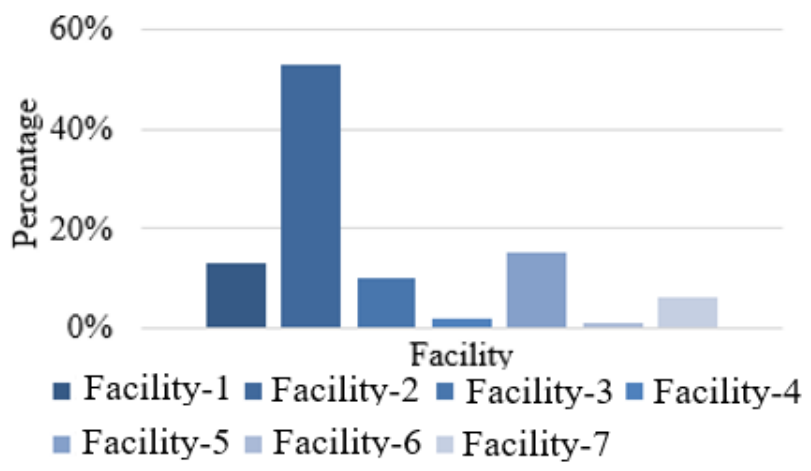

Figure 5. Percentage of facility choice in the station

Based on the survey result, the Zone 2-which is the waiting room - is the facility with highest visitors, therefore the waiting room is placed as close as possible with main access of the passengers and other facilities are placed according by its rank. The higher the percentage of the facility, the closer its space would be with the main access of the passengers, and vice versa, the lower the percentage of the facility, its space would be adjusted with the land availability. The accessibility between rooms become an important matter in designing passengers' circulation in the station, therefore the placement of each space are adjusted with the survey result, which could be seen in the desired line. The thicker the desiredd line means the larger the movement flow that occurs between the spaces; therefore the placement between them would be closer.

\subsection{Analysis of Performance Evaluation of Circulation in Tugu Railway Station}

Performance evaluation Yogyakarta Station would be used as consideration on Airport Railway Station location placement. According to Transit Cooperative Research Program (2013) and Network Rail (2011c), the performance evaluation on station could be conducted by analyzing passenger density and clearance times in platform area.

Analysis of passenger density in station was obtained by dividing the passenger volume with capacity $(v / c)$. If the ratio of $v / c$ is less than one, then the station serves smaller passenger volume than its capacity; while if the $v / c$ value is larger than one, then the station suffers from overcapacity. Graphic of passenger growth in Yogyakarta Station is shown in Figure 6.

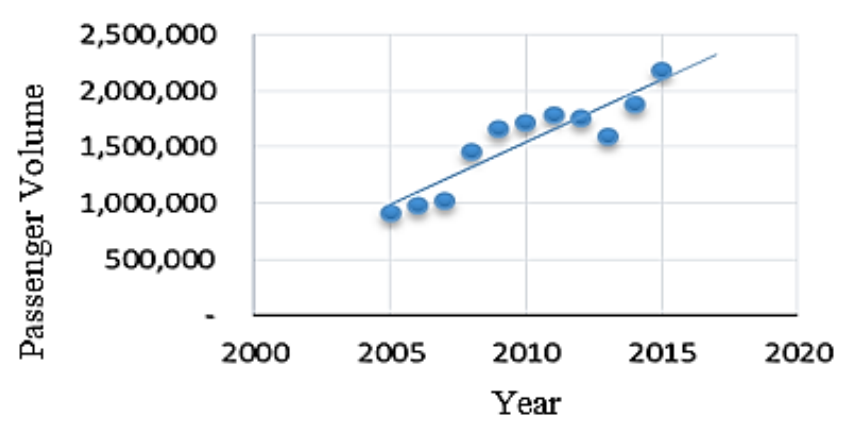

Figure 6. Passenger growth in Yogyakarta Station

Based on above mentioned data, the prediction of passenger volume on year 2018 is about $2,497,924$ 
passengers. This number is the volume of passengers using Yogyakarta Station as departure station. With the assumption that the number of passengers that use Yogyakarta Station as departure station is the same as the number of passengers that use Yogyakarta Station as destination station, the estimated total volume of passengers served by Yogyakarta in 2018 is 4,995,848 passengers. Furthermore, by using the formulation from Amtrak (2013), it resulted to total number of passengers per rush hour is 1.804 passengers/rush hour. With the waiting room area of Yogyakarta Station is around $850 \mathrm{~m}^{2}$, and estimation of total passengers per rush hour in year 2018 is 1,804 passengers/rush hour, the area size acquired for every passenger is around $0 ., 471 \mathrm{~m}^{2}$. Based on the Regulation of Ministry of Transportation Number 29 Year 2011 and the Standardization Guidelines for Indonesian Railways Station Year 2012, the required area size is 0.64 $\mathrm{m}^{2} /$ person; therefore, it could be said that Yogyakarta Station will suffer from overcapacity in terms of its construction on year 2018 .

In this research, determining the circulation performance at the platform area was stated with Level of Service in terms of the desired comfort level at the platform area and clearance times in platform area, which was obtained from the surveys. Based on observation and survey results in field location, there was clearance times difference among routes, which was affected by train type and passengers; for example, the clearance times in Track 1 is faster because it is intended for Prameks Train. Prameks Train is a commuter train with Yogyakarta - Solo route, therefore the train users are commuters that do not have a lot of luggage and already familiar with the station condition. Meanwhile, clearance times in Track 3 and 5 are relatively long because the type of passengers is longdistance passengers and the total number that to be served also relatively a lot more. Other than that, there is a contraflow in Track 3, and the passengers' access on Track 5 is obstructed by Sancaka Train, therefore clearance times are longer, and according to Network Rail, it is categorized to have Level of Service C.

\subsection{Selection of Location for Airport Railway Station}

Airport Railway Station is planned to be on large and international class. The selection of Airport Railway Station location was conducted by reviewing several aspects, which are the performance of Yogyakarta Station, National Spatial Plan and Detailed Spatial Plan of Yogyakarta City, and the area size owned by Indonesian Railways Company. Based on performance evaluation of the station that described in previous subchapter, it is predicted that in year 2018, Tugu Station would serve 1,804 passengers/rush hour, and would suffer from overcapacity in terms of its construction.
Based on the observation of field, train that has start and destination station on Yogyakarta will stop for a long time in certain track; therefore disrupting the access of railway passengers that are heading to trains or station exit. Other than that, based on the survey result, there is contraflow occurring on several locations, in which made the station categorized as Level of Service C, according to the Network Rail. Yogyakarta Station is also included in Cultural Heritage Building, which is grouped into a 'living monument', in which the building is still used from the start of the construction to the present. Based on the Law Number 11 Year 2010, building that is included into Cultural Heritage, shall not undergo any change on its main construction shape. On the basis of abovementioned matters, the Airport Railway Station should be designed separately from present Tugu Railway Station.

Because of no planning on Airport Railway Station in the Regional Regulation Number 2 Year 2010 regarding of Special Region of Yogyakarta Spatial Plan, hence the location selection would be conducted by reviewing Regional Regulation Number 1 Year 2015 regarding Detailed Spatial Plan of Yogyakarta City. Based on the Detailed Spatial Plan data, the railway station could be constructed on the public service zone and commerce and service zone. Therefore, the selected location for Airport Railway Station was on the northern part of Yogyakarta Station, as shown in Figure 7.

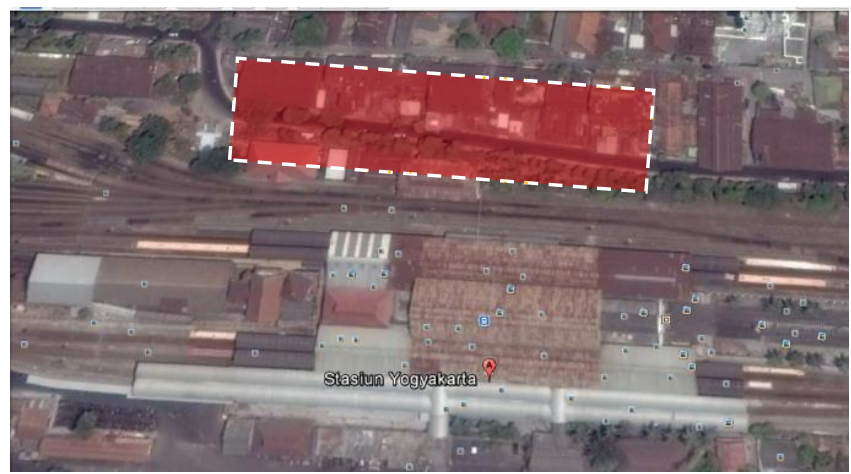

Figure 7. Plan for Airport Railway Station location (shown in red block)

\subsection{Layout of Airport Railway Station}

Layout of the station was designed with rooms that are according to the needs, and area sizes that are based on passengers' characteristic and necessity. Depiction of the station plan was based on additional route for circulation of the passengers, staffs, and retail manager. To facilitate the transformation on spatial pattern plan into station layout, a block design was constructed, as shown in Figure 8 and Figure 9. 


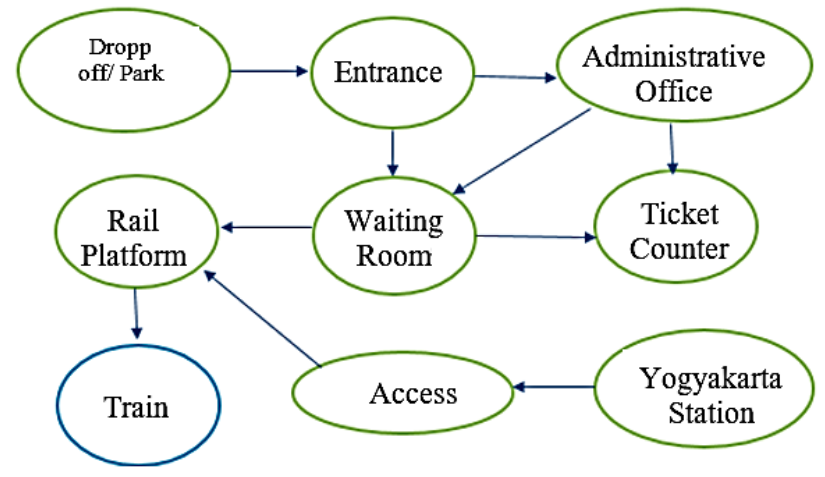

Figure 8. Block design of departure room on Airport Railway Station

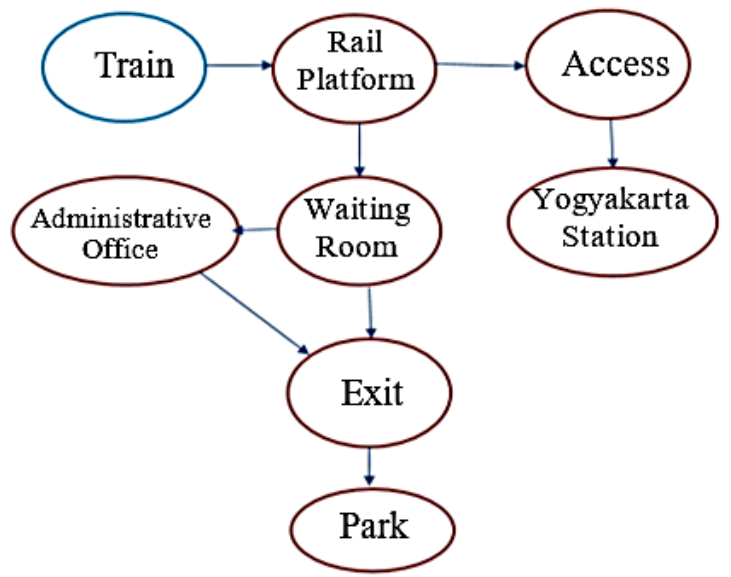

Figure 9. Block design of arrival room on Airport Railway Station

To maximize the available land, the station would be designed with two levels. First level is an entrance and exit access, waiting room, and administrative room. Second level is the waiting room, which is connected with a bridge that goes to the platform area. The station was designed to have two tracks; with the effective rail length is corresponding to the length of operating train, which is 8 cars plus with $50 \mathrm{~m}$ equals $225.6 \mathrm{~m}$. The platform in this station was designed to be placed between two tracks, or commonly called as island platform, with platform length $225.6 \mathrm{~m}$ and platform width for both tracks are $13 \mathrm{~m}$. Visualization of Airport Railway Station can be seen in Figure 10 and Figure 11.

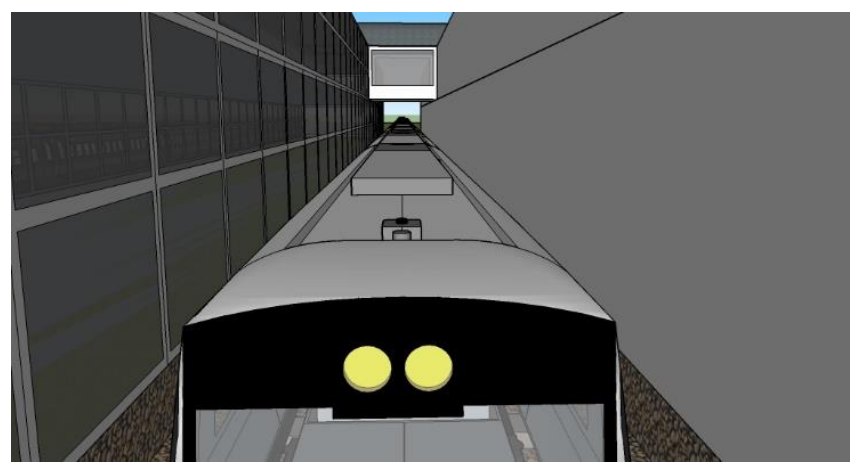

Figure 10. Photo visualization of interchange access between platform and track

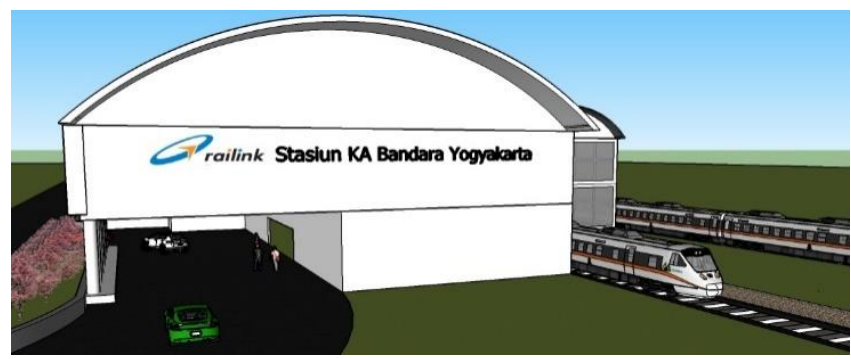

Figure 11. Photo Visualization of Airport Railway Station

\subsection{Zoning, Circulation, and Wayfinding}

Circulation is one of the points which became a benchmark of the success of a station because it will influence the efficiency and operation of a station. To create a good circulation, the station was divided into three service zones. Zone 1 is the entrance and exit

access of station, and also acts as connector between station and the surrounding area-in the form of entrance to drop-off area in the west side, or from the parking area in the east side of the station, and the access to exit the station from the west entrance door or the underpass.

Zone 2 is for prospective passengers with tickets and contains the facilities needed for passengers or nonpassenger users in the station. In this zone there are waiting room, toilet, retail shop, or even restaurant that are arranged based on the passengers' necessity, and also the station staff office. Zone 3 is for passengers with tickets and contains platform. To differentiate Zone 2 and Zone 3, the Automatic Tickets Gates (ATGs) is used. This is required, in order to be able to safely arrange the access in and out from the station.

Station zoning and the activity of station's users would determine the circulation pattern in the station. To transform the movement, a block design then is created, in order to state spatial plan based on zoning and its movement, as seen in Figure 12. 


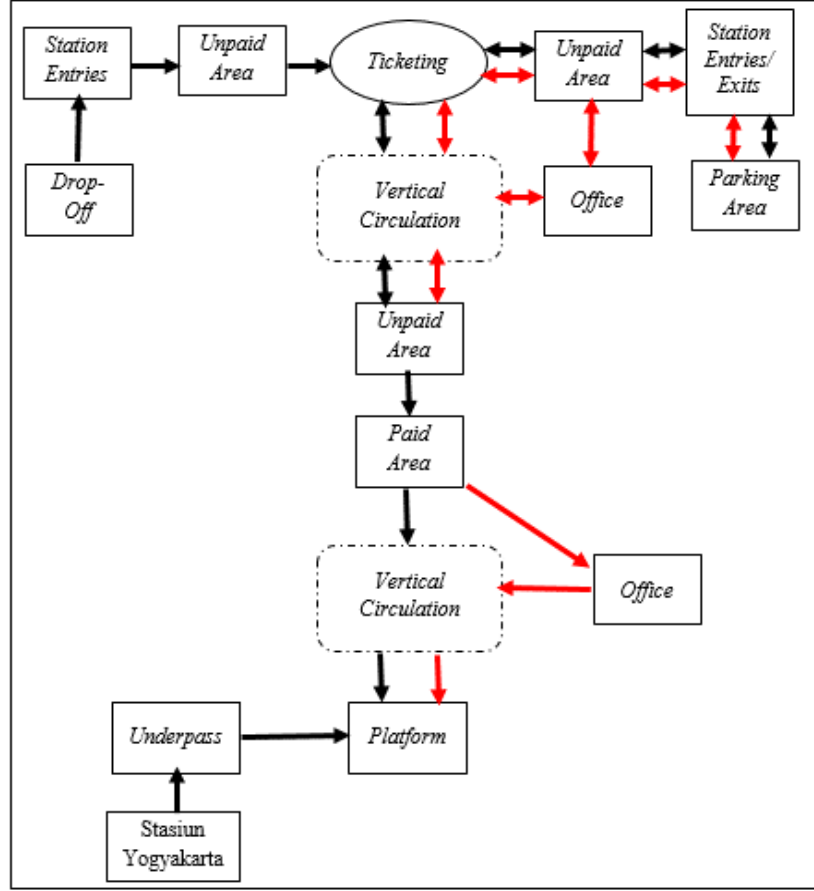

Figure 12. Block design and typicality of Airport Railway Station circulation

Information necessities on the Airport Railway Station that is integrated with the Tugu Railway Station are as follows: (1) static information in form of directional guide that is placed on three zones, the access zone that is located outside the station, facility zone that is located inside the station, and zone in the platform area; (2) dynamic information in form of railway information, the arrival station or station stops, and departure schedule. Both of the information is supported by audio information or information through the tactile paving. This paper only discussed the placement of static signs which would affect the wayfinding system. Design of the information forms that are consisted of information color, fonts, dimension and symbol, was using the standard in the wayfinding design; which was adapted from the Network Rail.

\section{CONCLUSIONS}

Based on the planning on the layout design of the Airport Railway Station which integrates with Tugu Railway Station, several conclusions could be made, as follows:

a) Station classification was based on Regulation of Minister of Transportation Number 33 Year 2011, which consisted of 6 criteria: based on the operation facility, total of railway tracks, supporting facility, traffic frequency, total daily passengers, and total goods. Accumulated credit score that obtained was 71 credit scores, which then made Airport Railway Station included in the category of large class station.

b) Room placement was based on the survey result of 100 respondents. The higher the percentage of the facility, the closer it will be with the main access of the passengers, and vice versa, the lower the percentage, the placement would be adjusted with the available land. In this case, majority of the respondents chose waiting room facility as the first facility to be visited; therefore in the designing, waiting room facility would be placed on the passengers' main access in the station, and other rooms' placement would be adjusted with each of its ranks.

c) Selection of the Airport Railway Station location was based on the performance of Yogyakarta Station and the Detailed Spatial Plan of Yogyakarta City, with description as follows;

- The assessment on the performance of circulation in Yogyakarta Station was conducted by analyzing the density in the station, in which prediction of passengers in 2018 was divided with the station capacity; and the performance of circulation in the platform area was evaluated by considering the comfort level and the clearance times. The result was the station density was $0.471 \mathrm{~m}^{2}$ per person, and the platform service level was on LOS C.

- The condition of Yogyakarta Station which is a Cultural Heritage Building, caused the station shall not undergo changes on its main construction shape, based on the Law Number 11 Year 2010.

- Because of the abovementioned matter, the determination of the Airport Railway Station location would be based on the Detailed Spatial Plan of Yogyakarta City. According to the Regional Regulation, the station development would only be granted permission on the public service zone, and the trade and service zone. Therefore, it was determined that the location of the Airport Railway Station is on the north of Yogyakarta Station, and would be integrated with the tunnel.

d) Station was designed as large and international class station, therefore in its designing, various references from abroad was used, and the calculation for room area was using the Level of Service A (3.24 $\mathrm{m}^{2}$ per person). 
e) In its circulation designing, the station was divided into three zones, which are Zone 1 that is the entrance and exit access of station; Zone 2 is for prospective passengers with tickets, in which it contained the facilities needed; Zone 3 is for passengers with tickets and contains platform. To support the movement of the passengers, static wayfinding system would be used.

\section{REFERENCES}

Amtrak, 2013. Station Program and Planning Guidelines. Montreal: Amtrak.

Anggoro, A., 2015. Desain Layout Stasiun Kereta Api Bandara dan Integrasinya dengan Bandar Udara (Studi Kasus: Stasiun Kereta Api Bandara, Kabupaten Kulon Progo, Yogyakarta), Yogyakarta: Master Thesis Report. Universitas Gadjah Mada.

Hunaify, M. S., 2015. Perancangan Geometrik Jalan Rel sebagai Transportasi Menuju Bandara Baru Yogyakarta dengan Memperhitungkan Faktor
Kebencanaan (Studi Kasus: Jalur Kereta Api Stasiun Kedundang - Bandara Baru Yogyakarta - Stasiun Wojo), Yogyakarta: Universitas Gadjah Mada.

Minister of Transportation, 2013. Decree of Minister of Transportation No. KP 1164 Year 2013 on Penetapan Lokasi dan Rencana Induk Bandara Baru Yogyakarta. Jakarta: Minister of Transportation.

PT. Railink, 2013. Manufacturing Specification for Diesel Electric Multiple Unit. Jakarta: PT. Railink.

Siregar, K., 2015. Analisis Prakiraan Permintaan Penumpang pada Rencana Pembangunan Kereta Api Bandara di Kulon Progo, Yogyakarta: Universitas Gadjah Mada.

Transit Cooperative Research Program, 2013. Transit Capacity and Quality of Service Manual Third Edition. Washington D.C.: Transportation Research Board. 